кандидат педагогічних наук, доцент (Житомирський державний університет імені Івана Франка) mironchuk nmei.ua ORCID: $0000-0002-1 \overline{3} 60-6381$

\title{
ФОРМУВАННЯ УМІНЬ САМООРГАНІЗАЦІЇ НАУКОВО-ДОСЛІДНИЦЬКОЇ ДІЯЛЬНОСТІ МАГІСТРАНТІВ НА ЗАСАДАХ ЕРГОНОМІЧНОГО ПІДХОДУ
}

\begin{abstract}
У статті окреслено зміст науково-дослідницької роботи викладача закладу вищої освіти. Визначено чинники зниження ефективності праці викладача вищої иколи у сучасних умовах. Названо приничии самоорганізації науково-дослідницької праці викладача вищої школи (творчого підходу, мобільності, динамічності, системності й послідовності, ергономічності наукової діяльності). Розглянуто окремі елементи самоорганізації праці викладача вищої школи у контексті вимог ергономічного підходу. Окреслено деякі види роботи магістрантів з формування у них умінь самоорганізації у науководослідницькій діяльності.
\end{abstract}

Ключові слова: самоорганізація, науково-дослідницька діяльність, ергономічний підхід.

Постановка проблеми у загальному вигляді. Одним із важливих функціонально-професійних завдань діяльності викладача вищої школи $\epsilon$ науково-дослідницька робота, яка перебуває у нерозривному взаємозв'язку із підвищенням власної науково-методичної кваліфікації та керівництвом науково-дослідницькою діяльністю студентів. Результати наукового пошуку викладача повинні відображатися й пов'язуватися 3 його практичною діяльністю, сприяти вдосконаленню процесу викладання і навчання студентів, формуванню в суб'єктів навчання фахових компетенцій. Змістом науково-дослідницької роботи викладача закладу вищої освіти є проведення наукових досліджень за тематикою науково-дослідної роботи кафедри й у межах особистих інтересів, пов'язаних із навчальнометодичною роботою і змістом предметів, які викладає педагог; підготовка отриманих наукових результатів до публікації у вигляді статей, доповідей, монографій, посібників; участь у обговоренні важливих наукових проблем на засіданнях кафедри, семінарах, нарадах, конференціях різного рівня, інших заходах освітньої установи; керівництво науково-дослідницькою роботою студентів та інше.

Ефективність науково-дослідницької роботи викладача залежить і від інтелектуальних, моральних, психічних, фізичних якостей викладача, умов праці, матеріально-технічного оснащення й обслуговування, і від рівня самоорганізації праці.

Аналіз основних досліджень і публікацій із зазначеної проблеми. Проблеми організації педагогічної діяльності з урахуванням вимог ергономічної науки досліджують О. Гервас, Є. Зімниця, Н. Карапузова, В. Помогайбо, О. Сорочинська; питання організації науково-дослідницької роботи 3 урахуванням ергономічних вимог - М. Оліяр, Г. Русин, І. Червінська. Дослідники розробляють ергономічно-педагогічні умови та дидактико-технологічні засоби забезпечення ефективної праці, розкривають ергономічні основи організації робочого середовища суб’єктів навчання в закладах загальної середньої освіти, досліджують вплив ергономічних компетенцій учителя на ефективність процесу навчання. Вважаємо положення ергономічної науки важливими для обгрунтування принципів самоорганізації й організації викладачами закладів вищої освіти продуктивної професійної діяльності.

Відтак метою статті $\epsilon$ визначення принципів і сутності самоорганізації викладачем науководослідницької діяльності на основі ергономічного підходу та представлення змісту і форм роботи магістрантів 3 формування у них умінь самоорганізації у науково-дослідницькій діяльності 3 урахуванням принципу ергономічності.

Виклад основного матеріалу 3 обгрунтуванням отриманих наукових результатів. Виконання професійних обов'язків потребує сформованості у викладача закладу вищої освіти високого рівня готовності й спроможності функціонувати в сфері "людина-людина", гнучкого реагування на умови освітньо-професійного середовища, розвиненої здатності організовувати свою працю на основі творчого пошуку та результатів власної дослідницької діяльності, спроможності якісно оновлювати свої знання й оволодівати новими технологіями праці, при цьому зберігаючи психічне здоров’я та життєву енергію.

На жаль, напружені умови праці, швидкий поступ освітніх змін і поява нових завдань у професійній сфері посилюють інтелектуальне та психофізичне навантаження на викладача, що може мати негативний вплив на якість та ефективність його професійної діяльності, а також стан його професійного здоров'я.

Вивчення допустимих фізичних, нервових, психічних навантажень на людину в процесі праці й розроблення на основі отриманих результатів рекомендацій щодо оптимізації умов і процесу діяльності здійснює ергономіка. Дослідження та розробки цієї науки спрямовані на створення передумов для розвитку та збереження людського потенціалу, що $\epsilon$ особливо важливим в умовах істотного інтелектуального та психофізичного навантаження у діяльності викладача вищої школи. 
На основі аналізу наукових робіт $[1 ; 2 ; 3]$ та результатів власних досліджень можемо визначити такі чинники зниження ефективності праці викладача: організаційно-структурні: відсутність або ненадійність технічного оснащення діяльності педагога; неналежне устаткування навчальних аудиторій; умови навчального середовища (освітленість, провітрюваність, температурний режим, ізольованість від шумів); неефективний менеджмент закладу / установи; виробничо-професійні: ступінь напруженості праці; спосіб організації колективної роботи; характер виконуваних функцій; характер розподілу робочих функцій; самоорганізаційні: недотримання режиму праці й відпочинку; несистемність / відсутність планування; недостатня самомотивація; недостатній рівень самодисципліни; особистіснопрофесійні: рівень професійної готовності; рівень самоорганізації особистості у професійній діяльності; індивідуально-психологічні: психофізіологічні та антропометричні характеристики; інтелектуальні особливості; емоційна та мотиваційна стійкість; вольові характеристики.

Самоорганізація у професійній педагогічній діяльності - це свідома діяльність особистості педагога, спонукувана й спрямована цілями та цінностями самокерування, організації, самовдосконалення у професійній діяльності та збереження професійного здоров'я, здійснювана системою інтелектуальних, мотиваційних, вольових дій і спрямована на вирішення завдань раціональної організації праці та ефективного виконання професійно-педагогічних завдань.

Самоорганізащія науково-досліднищької пращуі - це комплекс заходів організаційного та психофізіологічного змісту, які здійснюються безпосередньо дослідником для забезпечення системи і чіткості в роботі. Самоорганізація науково-дослідницької праці передбачає дії дослідника 3 аналізу проблеми, цілевизначення, планування, конструювання, моделювання дослідницького пошуку, включає виконавські дії (вибір рішення та його реалізація, організація робочого місця і зони, дотримання режимів робочого часу та відпочинку, розподіл особистісних та просторово-часових ресурсів), саморегулювання, самоконтроль й, відповідно, спрямована на підвищення ефективності дослідницької роботи, збереження ресурсів енергії, часу та власного здоров'я.

Самоорганізація науково-дослідницької праці викладача здійснюється 3 урахуванням таких принципів: творчого підходу - прагнення на всіх етапах дослідження пояснити факти, явища, предмети, віднайти нове в науці; мобільності - здатність адаптуватися до змін функцій та місця роботи; динамічності - спроможність гнучко й оперативно координувати власні дії відповідно до темпів розвитку науки; системності та послідовності - попереднього планування; виконання простих дій перед більш складними / творчими; прогнозування та передбачення результатів; дотримання етапів роботи; самоконтролю; ергономічності наукової діяльності - дотримання дисципліни та самодисципліни; забезпечення чіткості та порядку в організації робочого місця, роботи 3 технічними засобами; раціональний розподіл часу; самоконтроль та самооблік діяльності.

Розглянемо окремі елементи самоорганізації дослідницької праці викладача у контексті вимог ергономічної науки. Планування діяльності викладача-дослідника, як найважливіша складова частина організації особистої праці, означає підготовку до реалізації визначеної мети (розроблених стратегічних і тактичних цілей роботи) і структуризацію (впорядкування) робочого часу.

Загальну спрямованість дослідження та послідовність його проведення визначає робочий план дослідника. Робочий план складається на основі чіткого усвідомлення предмету дослідження, мети, завдань дослідницької роботи, базової гіпотези. Його розробка передбачає аналітичну діяльність педагога 3 метою визначення тактичних дій, спрямованих на реалізацію стратегічних завдань дослідження.

Окрім розроблення робочого плану, планування роботи педагога-дослідника передбачає складання ним плану-проспекту (реферативне укладання змісту дослідницької роботи), плану-графіка роботи (визначення конкретних організаційних дій та термінів їх здійснення) тощо з урахуванням ступеня складності дослідницької роботи, термінів виконання, витрат часу та інших ресурсів, передбачення резервів часу тощо.

Планування дослідницької роботи здійснюється з урахуванням режиму праці й відпочинку. Режим праці й відпочинку має базуватися на звичному, повсякденному розпорядку дня й бути стереотипним, постійним. Є загальні рекомендації учених щодо регламентації періоду праці та відпочинку: загальний час зайнятості на добу повинен складати не більше 10 годин, загальна тривалість відпочинку - не менше 9,5 год. до 10,5 год., загальна тривалість сну - не менше 8 год., а безперервного сну - не менше 6,5-7 годин на добу. Дослідники вважають найбільш ефективним періодом доби для здійснення наукової діяльності першу половину дня (з 8 до 15 год.), а також пообідні (з 16 до 19 год.) і вечірні години (з 20 до 22 год.) [5: 54-55].

Робоче місие - зона трудових дій, оснащена предметами, меблями та засобами праці. Раціональна організація робочого місця передбачає упорядкування й розташування його елементів відповідно до характеру трудової діяльності з метою створення зручних умов праці, запобігання шкідливому впливу негативних факторів зовнішнього середовища, а також оснащення елементами, які підвищують рівень комфортності, зручності та економності виконання діяльності. 
Упорядкування елементів робочого місця повинне здійснюватися з урахуванням принципів [5: 54]: досяжності (таке розташування робочих матеріалів та засобів, яке дозволяє уникати зайвих рухів, що призводять до втоми чи додаткових втрат часу); оглядовості (систематизація матеріалів, забезпечення постійного місця для використовуваних у роботі речей); ізольованості (усунення подразнюючих чинників, сторонніх предметів, відсторонення від інших суб'єктів діяльності (продумане розташування меблів, засобів праці, використання перегородок, засобів абстрагування від зайвих шумів)). Ергономічний підхід до самоорганізації праці педагога передбачає також урахування показників освітлення, температури, провітрюваності, загальної атмосфери приміщення, пов'язаної 3 рекомендаціями хромо- та аромотерапії.

Проведені нами дослідження, результати яких ми подаємо в своїх публікаціях [4], засвідчують необхідність сформованості високого рівня самоорганізації педагогічної праці з метою підвищення ії продуктивності та збереження професійного здоров'я викладача.

Підготовка студентів магістратури спеціальності 011 "Освітні, педагогічні науки" до професійної ролі викладача закладу вищої освіти, в тому числі й до науково-дослідницької роботи, у Житомирському державному університеті імені Івана Франка здійснюється комплексно через залучення студентів до виконання відповідних професійних ролей у процесі навчальної / навчально-професійної діяльності у контекстному середовищі освітнього закладу.

Засвоєння магістрантами теорії та формування практичних умінь і навичок самоорганізації у навчальній / навчально-професійній діяльності на основі рефлексії набутих компетентностей та особистого досвіду самоорганізації, розвиток у них ціннісного ставлення до власної особистості й вироблення практики позитивного самомотивування, стимулювання потреби продуктивно використовувати особистісні ресурси задля власного успіху і забезпечення професійної ефективності відбувається у процесі вивчення навчальної дисципліни "Основи самоорганізації у професійній діяльності". Логіка засвоєння змісту навчальної інформації та формування умінь самоорганізації в магістрантів передбачає послідовне вивчення таких тем: 1) Психолого-педагогічні умови забезпечення ресурсу активності та працездатності педагога. 2) Самоорганізація педагога у професійно-педагогічній діяльності. 3) Постановка цілі у професійній педагогічній діяльності. 4) Планування особистої роботи педагога. 5) Самомотивування у роботі педагога. 6) Самоаналіз та самоконтроль у професійній діяльності. 7) Предметно-просторова самоорганізація у педагогічній діяльності. 8) Організація науководослідницької діяльності педагога.

Розвиток умінь самоорганізації відбувається у контексті ситуаційних факторів життєдіяльності студентів магістратури у навчальному закладі (планування та розподіл ресурсів (часу, простору, особистих можливостей) у межах виконання навчальної роботи, здійснення дослідницького пошуку), в процесі модельованих навчальних ситуацій (через самопізнання своїх особливостей у процесі педагогічної діагностики, шляхом спеціальних вправ, ігрових і рефлексивних методів 3 метою навчання цілевизначення, планування особистої роботи, самомотивування, самоаналізу та самоконтролю діяльності, закріплення поведінки організованої людини в навчальних ситуаціях і модельованих ситуаціях професійної діяльності), під час самостійної роботи.

Вивчення теми "Організація науково-дослідницької діяльності педагога" в змісті навчальної дисципліни передбачає з'ясування магістрантами загальних принципів організації наукової праці дослідника, конкретизацію вимог щодо раціональної організації праці педагога (розподіл ресурсів робочого часу та відпочинку; урахування складності різних видів робіт та їх чергування; упорядкування робочої зони; дотримання показників освітлення, температурного режиму, повітря; використання атрибутів дослідницької праці; встановлення оптимальних для роботи годин та ін.).

Рефлексія змісту теми практичного заняття передбачає укладання магістрантами картки-схеми практичного заняття, де зазначено мету власної діяльності (за функціями процесу навчання); нові поняття, які опрацьовано у процесі підготовки; методи самоорганізації, застосовані під час опрацювання навчальної теми.

Магістранти отримують завдання розробити і представити на занятті план виконання дослідницької роботи $з$ обгрунтуванням конкретних дій та прогнозованих результатів роботи; розробляють плани роботи для виконання проектних завдань, для реалізації програм особистісно-професійного самовдосконалення; практично розв'язують ситуації самоорганізації, пов'язані з виконанням наукового напряму роботи викладача вищої школи. Подаємо для прикладу кілька проблемно-ситуаційних завдань:

1) Викладач отримав завдання виступити на теоретико-методологічному семінарі 3 доповіддю "Самоорганізація викладача закладу вищої освіти в професійній діяльності". Засідання семінару має відбутися через три тижні. Які, на Ваш погляд, аспекти самоорганізації викладач повинен розкрити? Визначте вид самоорганізації викладача. Вкажіть, які знання, уміння та навички мають бути сформовані у педагога. Складіть план (тези) виступу. Проаналізуйте роль теоретико-методологічного семінару в професійному розвитку викладача вищої школи. 
2) Вас призначено науковим керівником студента, який виконує дипломну роботу. Складіть план роботи зі студентом-дипломником, щзоб якісно $i$ вчасно виконати науково-дослідницьку роботу. Назвіть вимоги до виконання дипломної роботи. Вкажіть вид самоорганізачї викладача.

Вирішення таких завдань, які відтворюють один із напрямів контексту майбутньої професійної діяльності викладача вищої школи (іх аналіз, проектування способів дій та пошук варіантів рішень, програвання ситуацій), створює можливість для перетворення та синтезування теоретичних знань у практичний досвід і безпосередньо закладає основи розуміння типових для професійної діяльності завдань.

У процесі осмислення педагогічного завдання й самостійного пошуку наукових способів його вирішення магістранти засвоюють педагогічні знання, набувають умінь обгрунтованого й поглибленого аналізу професійних явищ, моделювання, проектування, конструювання рішення, варіанту поведінки; удосконалюють навички самоаналізу, самооцінки, самоконтролю; набувають здатностей до вияву варіативності, гнучкості у виборі стратегій дій, вчинку; виявляють готовність до активного особистісного сприйняття професійно-педагогічних ситуацій та самоорганізації у процесі їх виконання.

Висновки та перспективи подальшого дослідження проблеми. Отже, науково-дослідна діяльність викладача закладу вищої освіти є одним із напрямів його професійної діяльності, нерозривно пов'язана 3 навчально-педагогічною, навчально-методичною, організаційною, виховною та іншими видами педагогічної роботи, й в умовах підвищення інтелектуального та психоемоційного навантаження на викладача має здійснюватися на основі ефективної самоорганізації професійної діяльності та 3 урахуванням низки ергономічних принципів.

Самоорганізація викладачем науково-дослідної роботи сприяє вдосконаленню і впорядкуванню цього процесу й залежить від ступеня реалізації таких вимог: урахування факторів залежності розумової працездатності (внутрішніх: інтелектуальних здібностей, стану здоров'я, волі, ступеня тренованості; зовнішніх: обстановки, зовнішнього середовища, робочого місця, робочої ситуації, режиму праці та відпочинку); зважання на типові фази працездатності (упродовж доби, тижня) та індивідуальні біоритми; дотримання відповідних робочих умов (упорядкування робочих зон; унормування освітлення, звукового поля, чергування праці й відпочинку, фізичної та розумової діяльності, різнорідних процесів наукової роботи (читати, слухати, писати, дивитися, говорити і т.п.); температурного режиму).

Навчання магістрантів методам самоорганізації та їх застосування у процесі виконання навчальних $\mathrm{i}$ завдань дослідницького пошуку сприяє формуванню та закріпленню необхідних знань, умінь, навичок, підвищує мотивацію до педагогічної праці, виробляє ціннісні орієнтації щодо професійної діяльності та саморозвитку, підвищує рівень організованості студента, що у майбутньому переноситься на реальні життєві й професійні ситуації. Перспектива подальшого пошуку полягає в перевірці ефективності методики формування умінь самоорганізації у професійній діяльності в майбутніх викладачів вищої школи.

\section{СПИСОК ВИКОРИСТАНИХ ДЖЕРЕЛ I ЛІТЕРАТУРИ}

1. Сорочинська О. Л. Основи ергономіки : конспект лекцій / О. Л. Сорочинська. - К. : ДЕТУТ, 2014. - 106 с.

2. Дусь Н. А. Феноменологія емоційного вигорання в педагогічній діяльності : психологічні особливості та шляхи профілактики / Н. А. Дусь, Н. С. Потримай // Проблеми освіти : [зб. наук. праць]. - Вінниця-Київ, 2015. - Вип. 82. - С. 85-89.

3. Тринус О.В. Проблема визнання статусу молодого вчителя в Україні / О. В. Тринус // ScienceRise : Pedagogical Education. - 2017. - № 1(9). - С. 15-19.

4. Мирончук Н. М. Роль планування в забезпеченні ефективності професійної діяльності викладача вищого навчального закладу / Н. М. Мирончук // Проблеми освіти : [наук.-метод. збірник]. - Спецвипуск. - Київ, 2015. № 85. - C. $82-88$.

5. Оліяр М.П. Основи науково-педагогічних досліджень (модульно-рейтинговий підхід) : [навч.-метод. посібн.] / Оліяр М. П., Русин Г. А., Червінська І. Б. - Івано-Франківськ : НАIP, 2013. - 214 с.

\section{REFERENCES (TRASLATED \& TRANSLITERATED)}

1. Sorochynska O. L. Osnovy erhonomiky : konspekt lektsii [Fundamentals of Ergonomics : a Summary of Lectures] / O. L. Sorochynska. - K. : DETUT, 2014. - $106 \mathrm{~s}$.

2. Dus N. A. Fenomenolohiia emotsiinoho vyhorannia v pedahohichnii diialnosti : psykholohichni osoblyvosti ta shliakhy profilaktyky [Phenomenology of Emotional Burnout in Pedagogical Activity: Psychological Peculiarities and Ways of Prevention] / N. A. Dus, N. S. Potrymai // Problemy osvity [Problems of Education] : zb. nauk. prats'. Vinnytsia-Kyiv, 2015. - Vyp. 82. - S. 85-89.

3. Trynus O. V. Problema vyznannia statusu molodoho vchytelia v Ukraini [The Problem of Recognition of the Status of a Young Teacher in Ukraine] / O. V. Trynus // ScienceRise : Pedagogical Education. - 2017. - № 1(9). - S. 1519.

4. Myronchuk N. M. Rol planuvannia v zabezpechenni efektyvnosti profesiinoi diialnosti vykladacha vyshchoho navchalnoho zakladu [The Role of Planning in Ensuring the Effectiveness of the Professional Activity of a Teacher 
of a Higher Educational Institution] / N. M. Myronchuk // Problemy osvity [Problems of Education] : [nauk.-metod. zbirnyk]. - Spetsvypusk. - Kyiv, 2015. - № 85. - S. 82-88.

5. Oliiar M. P. Osnovy naukovo-pedahohichnykh doslidzhen (modulno-reitynhovyi pidkhid) [Fundamentals of Scientific and Pedagogical Research (Modular-Rating Approach)] : [navch.-metod. posibn.] / Oliiar M. P., Rusyn H. A., Chervinska I. B. - Ivano-Frankivsk : NAIR, 2013. - 214 s.

\section{Мирончук Н. Н. Формирование умений самоорганизации научно-исследовательской деятельности магистрантов на основе эргономического подхода.}

В статье обозначено содержание научно-исследовательской работы преподавателя высшего учебного заведения. Определены факторы снижения эффективности труда преподавателя высшей школь.

Названы принципы самоорганизации научно-исследовательской работы преподавателя высшей школь (творческого подхода, мобильности, динамичности, системности и последовательности, эргономичности научной деятельности). Рассмотрены отдельные элементы самоорганизации труда преподавателя высшей школь в контексте требований эргономического подхода. Определены некоторые виды работы магистрантов по формированию у них умений самоорганизации в научноисследовательской деятельности.

Ключевые слова: самоорганизация, научно-исследовательская деятельность, эргономический подход.

\section{Myronchuk N. M. Formation of Skills of Self-Organization of Research Activity of Master Students on the Basis of Ergonomic Approach.}

The article outlines the content of the teacher's of higher education institution research work. The factors of reducing the efficiency of the work of a teacher of higher education in modern conditions (organizationalstructural, industrial-professional, personal-professional, self-organizing, individual-psychological) are determined. The principles of self-organization of scientific work of a teacher of higher education (creative approach, mobility, dynamism, systemic and consistency, ergonomics of scientific activity) are named. Some elements of the self-organization of the research activity of the lecturer in the context of the requirements of ergonomic science (planning of work, adherence to the regime of work and rest, organization of the workplace) are considered. The subjects of practical classes in the discipline "The basis of self-organization in professional activity" are presented: 1) psychological and pedagogical conditions for providing the resource of activity and ability of the teacher; 2) self-organization of the teacher in professional activities; 3) goals in professional pedagogical activity; 4) planning of the teacher's personal work; 5) self-motivation in the work of the teacher; 6) self-analysis and self-control in professional activities; 7) subject-spatial self-organization in pedagogical activity; 8) organization of the teacher's research activities. Some types of work of future lecturers with the purpose of forming their skills in self-organization of research activities are named: drawing up a scheme of practical classes, developing a plan for the completion of the thesis, developing a plan of work for the project task; solution of problem-situational tasks.

Key words: self-organization, research activity, ergonomic approach. 